\title{
SOCIAL ENTERPRISE FOR EMPOWERMENT OF WOMEN FROM ETHNIC MINORITY: CHALLENGES AND POSSIBILITIES
}

\author{
Česlovas Christauskas \\ Rasa Žilionè \\ Innovation Office, Lithuania
}

Kaunas University of Applied Sciences, Lithuania

\begin{abstract}
The empowerment of women and the improvement of their political, social, economic and health status is a highly important and is one of the Global Sustainable Goals. Gender Equality index 2020 of EU-28 is 67.9, slowly increasing (European Institute for Gender Equality, 2021). Although there are some researches related to women empowerment and economic development (Siba, 2019, Hemalatha, 2020, Doss, Malapit, \& Comstock, 2020, etc.) or social entrepreneurship (Biggeri, Testi, Bellucci, During, \& Persson, 2018; BriarLawson, Miesing, \& Ram, 2020, etc.), combining these two fields and especially adding women from ethnic minority is very rare in scientific researches.

The aim of the paper is to highlight challenges and possibilities of social entrepreneurship for empowerment of women from ethnic minority.

This paper is based on Erasmus + project "Empowering Women from Ethnic Minorities Through Social Enterprises" (abbrev. EMwoSE) analysis of both quantitative and qualitative data retrieved in Ireland, United Kingdom, Germany, Greece, Italy, Lithuania and Turkey. International data gives to the paper additional value in picturing the bigger picture of the situation in European countries.

However, women starting a social enterprise is itself contributing to women's empowerment, assuming that social enterprise can be culturally more acceptable for women from ethnic minorities.
\end{abstract}

Keywords: empowerment, entrepreneurship, ethnic minority, social enterprise, women.

\section{Introduction}

The empowerment of women and the improvement of their political, social, economic and health status is a highly important and is one of the Global Sustainable Goals (United Nations, 2015). Gender Equality index 2020 of EU28 is 67.9, slowly increasing (European Institute for Gender Equality, 2021).

The aim of the paper is to highlight challenges and possibilities of social entrepreneurship for empowerment of women from ethnic minority.

This paper is based on Erasmus+ project "Empowering Women from Ethnic Minorities Through Social Enterprises" (abbrev. EMwoSE) analysis of 
Christauskas \& Žilione, 2021. Social Enterprise for Empowerment of Women From Ethnic Minority: Challenges And Possibilities

both quantitative and qualitative data retrieved in Ireland, United Kingdom, Germany, Greece, Italy, Lithuania and Turkey. International data gives to the paper additional value in picturing the bigger picture of the situation in European countries.

\section{Social Entrepreneurship as Tool for Empowerment of Women from Ethnic Minority: Theoretical Background}

Empowerment is the process of increasing the capacity of individuals or groups to make choices and to transform those choices into desired actions and outcomes (Petesch, Smulovitz, \& Walton, 2005). Mandal (2013) distinguishes five types of empowerment: social, educational, economic, political and psychological.

Referring to European Commission (2021), work is the best way to empower women economically. Unfortunately, women still remain underrepresented in the labour market. $67 \%$ of women are currently in employment, whereas men's employment stands at $79 \%$. Gender employment gap is $12 \%$. Moreover, the burden of private and care responsibilities, the unpaid work, still rests largely on women's backs.

Women constitute only $34.4 \%$ of the self-employed in the EU and $30 \%$ of start-up entrepreneurs (European Parliament, 2020). Social entrepreneurship has been key in promoting women empowerment. Although there are some researches related to women empowerment and economic development (Siba, 2019, Hemalatha, 2020; Doss, Malapit, \& Comstock, 2020, etc.) or social entrepreneurship (Biggeri, Testi, Bellucci, During, \& Persson, 2018; BriarLawson, Miesing, \& Ram, 2020, etc.), combining these two fields and especially adding women from ethnic minority is very rare in scientific researches.

However, women starting a social enterprise is itself contributing to women's empowerment, assuming that social enterprise can be culturally more acceptable for women from ethnic minorities.

Europe hosts the largest number of international migrants (82 million), followed by Northern America (59 million) and Northern Africa and Western Asia (49 million). Moreover, women represented 51.4\% of migrants in Europe (United Nations, 2019).

Therefore, women from ethnic minorities is large enough part in Europe, therefore, the scientists should pay more attention to these women issues in order to provide recommendations for practitioners in order to ensure more effective ways to overcome the problems.

Beside this, while focusing on the lack of scientific researches combining fields such as women empowerment and economic development, social 
entrepreneurship as well ethnic minorities, the paper is based on empirical research in order to fill these gaps.

\section{Methodology of the Research}

As lack of the scientific researches was determined while analysing previous findings, empirical research was made in the framework of two-year Erasmus + project EMwoSE. The research provides both quantitative and qualitative data by women from ethnic minorities and experts in the field (providing education and training, business consulting, supporting immigrant women refugees, legal support, etc.). The research was aimed to reveal challenges and possibilities of social entrepreneurship for empowerment of women from ethnic minority.

Research sample. The survey results from 105 women from ethnic minorities working in social enterprises and survey results from 79 expert agencies or organisations that support women in social enterprises have been collected. The survey results are from seven European countries (Ireland, UK, Germany, Greece, Italy, Lithuania, and Turkey).

Research instrument and procedure. A questionnaire "Empowering Women from Ethnic Minorities Through Social Enterprise" was designed and developed by partners of the project EMwoSE. The questionnaire mainly focused on understanding of women from ethnic minorities, regarding the existing knowledge, practical skills that they needed, challenges and obstacles in order to get engaged to the social enterprise world. Here, in the paper, only part of the received data will be analysed.

Data analysis. The quantitative data was analysed through descriptive statistical analysis techniques. The frequencies, percentages, and average/mean scores are calculated and presented in figures.

\section{Findings of the Research}

Revealing challenges. The participants were asked to describe the challenges women from ethnic minorities face working in their business. The results are presented in Figure 1 below.

According to findings in Figure 1, the biggest part of women has faced language barriers throughout their business life, following by difficulties reaching the target groups, and lack of interest. The number of women facing cultural barriers, stereotypes of the local community, their own ethnic minority traditions/attitude towards women employment. 
Christauskas \& Žilione, 2021. Social Enterprise for Empowerment of Women From Ethnic Minority: Challenges And Possibilities

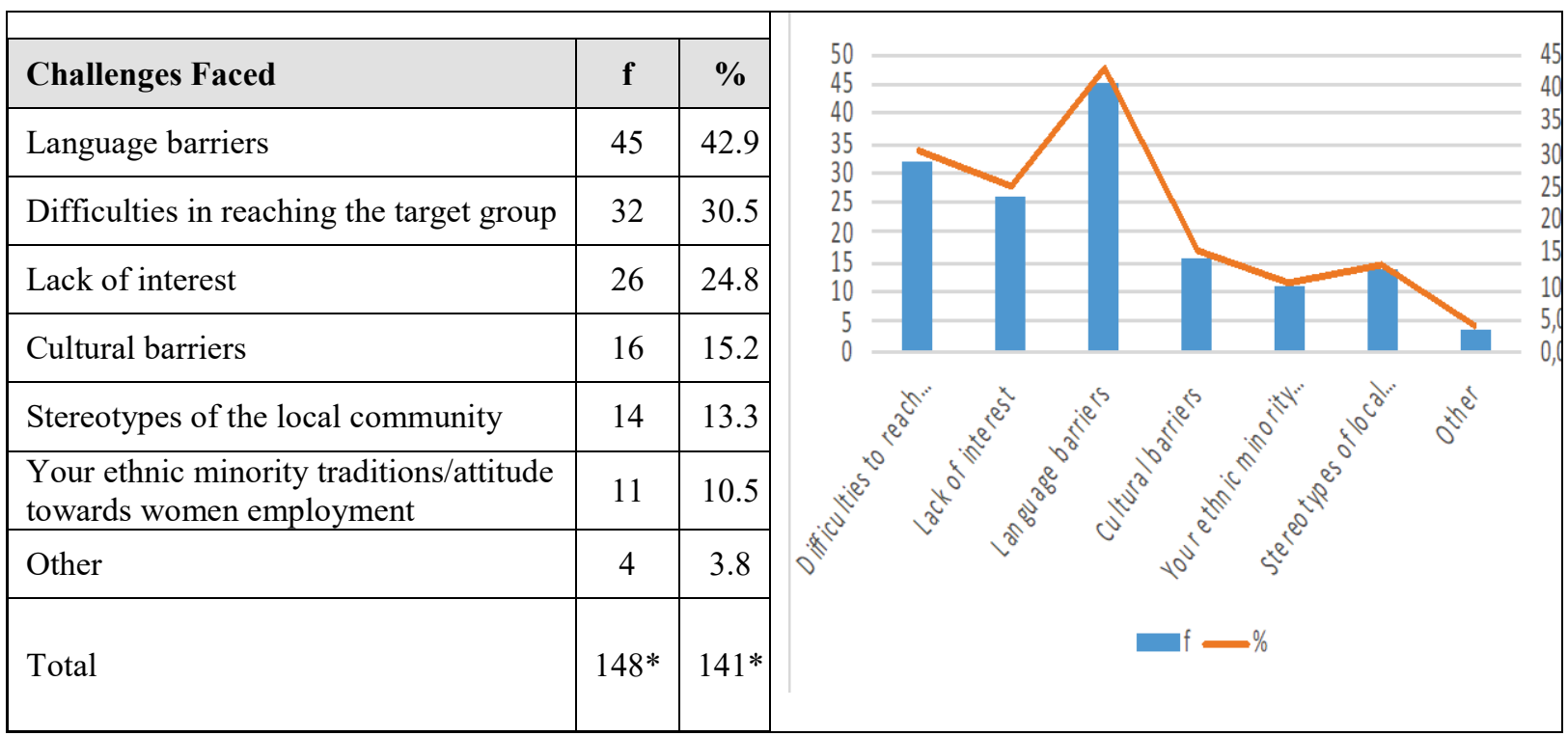

*: Participants was able to respond with multiple answers. Hence total frequency (148) is more than the number of participants (105). Thus, the total response is more than $100 \%$.

Figure 1 The Challenges Women from Ethnic Minorities Face Working in their Business (EMWOSE, 2020)

Table 1 To What Extent Women Agree with the Challenges They Face in Their Organization (EMWOSE, 2020)

\begin{tabular}{|c|c|c|c|c|c|c|}
\hline Barriers and Obstacles & 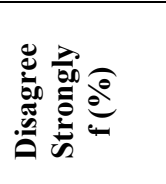 & 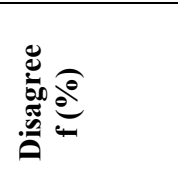 & 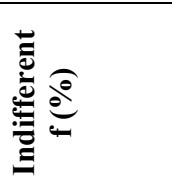 & 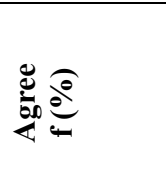 & 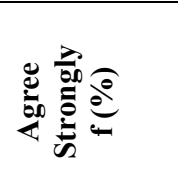 & 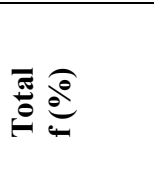 \\
\hline $\begin{array}{l}\text { Social (low public awareness, } \\
\text { social integration etc.) }\end{array}$ & $10(10.8 \%)$ & $10(10.8 \%)$ & $21(22.6 \%)$ & $31(33.3 \%)$ & $21(22.6 \%)$ & $93(100 \%)$ \\
\hline $\begin{array}{l}\text { Financial (business plan/model, } \\
\text { financial literacy etc.) }\end{array}$ & $7(7.7 \%)$ & $12(13.2 \%)$ & $15(16.5 \%)$ & $35(38.5 \%)$ & $22(24.2 \%)$ & $91(100 \%)$ \\
\hline $\begin{array}{l}\text { Cultural (market attitudes, beliefs } \\
\text { and expectations etc.) }\end{array}$ & $10(11.1 \%)$ & $9(10 \%)$ & $20(22.2 \%)$ & $31(34.4 \%)$ & $20(22.2 \%)$ & $90(100 \%)$ \\
\hline $\begin{array}{l}\text { Psychological (Lack of self- } \\
\text { confidence, lack of self-esteem } \\
\text { etc.) }\end{array}$ & $11(12.4 \%)$ & $16(18 \%)$ & $11(12.4 \%)$ & $22(24.7 \%)$ & $29(32.6 \%)$ & $89(100 \%)$ \\
\hline \multicolumn{7}{|l|}{ Entry into the business sector } \\
\hline & $11(12.5 \%)$ & $15(17 \%)$ & $7(8 \%)$ & $33(37.5 \%)$ & $22(25 \%)$ & $88(100 \%)$ \\
\hline $\begin{array}{l}\text { Institutional (lack of personnel } \\
\text { with commercial acumen) }\end{array}$ & $11(12.9 \%)$ & $15(17.6 \%)$ & $17(20 \%)$ & $28(32.9 \%)$ & $14(16.5 \%)$ & $85(100 \%)$ \\
\hline
\end{tabular}


The individuals who took part in the survey were mostly either agreed or strongly agreed, that the above-mentioned challenges are truly faced by the women from ethnic minorities. Among the listed challenges, social (low public awareness, social integration etc.) 93\%, financial (business plan/model, financial literacy etc.) $91 \%$, and cultural (market attitudes, beliefs and expectations etc.) $90 \%$ found to be the mostly frequent by the women form ethnic minorities.

The survey has revealed that most of women do not feel any barriers regarding the fact they belong to ethnic minority, but others feel to be discriminated comparing with locals, have language barrier. So, communication problems/language barriers, financial issues, childcare provision, cultural barriers and housing issues are on the top of issues faced by women from ethnic minority (Table 2).

Table 2 To What Extent Women Agree with the Issues They Face When Working in Business (EMWOSE, 2020)

\begin{tabular}{|c|c|c|c|c|c|c|c|c|c|c|c|c|}
\hline \multirow[t]{2}{*}{$\begin{array}{l}\text { Issues and } \\
\text { Challenges }\end{array}$} & \multicolumn{2}{|c|}{ Disagree Strongly } & \multicolumn{2}{|c|}{ Disagree } & \multicolumn{2}{|c|}{ Indifferent } & \multicolumn{2}{|c|}{ Agree } & \multicolumn{2}{|c|}{$\begin{array}{c}\text { Agree } \\
\text { Strongly }\end{array}$} & \multirow[t]{2}{*}{ Total } & \multirow[t]{2}{*}{ Avg. } \\
\hline & $\mathrm{f}$ & $\%$ & $\mathrm{f}$ & $\%$ & $\mathrm{f}$ & $\%$ & $\mathrm{f}$ & $\%$ & $\mathrm{f}$ & $\%$ & & \\
\hline $\begin{array}{l}\text { Communication } \\
\text { problems / } \\
\text { Language } \\
\text { barriers }\end{array}$ & 15 & 17 & 11 & 12.5 & 9 & 10.2 & 25 & 28.4 & 28 & 31.8 & $\begin{array}{c}88 \\
(\% 100)\end{array}$ & 3.45 \\
\hline Financial issues & 15 & 15 & 10 & 10.4 & 17 & 17.7 & 25 & 26 & 29 & 30.2 & $\begin{array}{c}96 \\
(\% 100)\end{array}$ & 3.44 \\
\hline $\begin{array}{l}\text { Childcare } \\
\text { provision }\end{array}$ & 17 & 17 & 18 & 18 & 15 & 15 & 23 & 23 & 24 & 24 & $\begin{array}{c}97 \\
(\% 100)\end{array}$ & 3.19 \\
\hline $\begin{array}{l}\text { Cultural } \\
\text { barriers }\end{array}$ & 15 & 15 & 17 & 17 & 13 & 13 & 37 & 37 & 18 & 18 & $\begin{array}{c}100 \\
(\% 100) \\
\end{array}$ & 3.16 \\
\hline Housing issues & 17 & 17.5 & 11 & 11.3 & 24 & 24.7 & 30 & 30.9 & 15 & 15.5 & $\begin{array}{c}97 \\
(\% 100)\end{array}$ & 3.15 \\
\hline
\end{tabular}

As can be seen from Table 2 above, together with the "Communication Problems / Language Barrier (avg.=3.45)" and the "Financial issues (avg.=3.44)" found to be the more challenging issues for the women from ethnic minorities in SEs. Moreover, the majority of the women agreed that they have faced challenges and barriers in all areas in the given list.

While entering the market, women form ethnic minorities have faced such problems and challenges as lack of financial resources ( $\mathrm{f}=38 ; 57.6 \%)$, human resources $(\mathrm{f}=17 ; 25.8 \%)$, lack of contacts/networking $(\mathrm{f}=17 ; 25.8 \%)$, etc. (Figure 2). 
Christauskas \& Žilione, 2021. Social Enterprise for Empowerment of Women From Ethnic Minority: Challenges And Possibilities

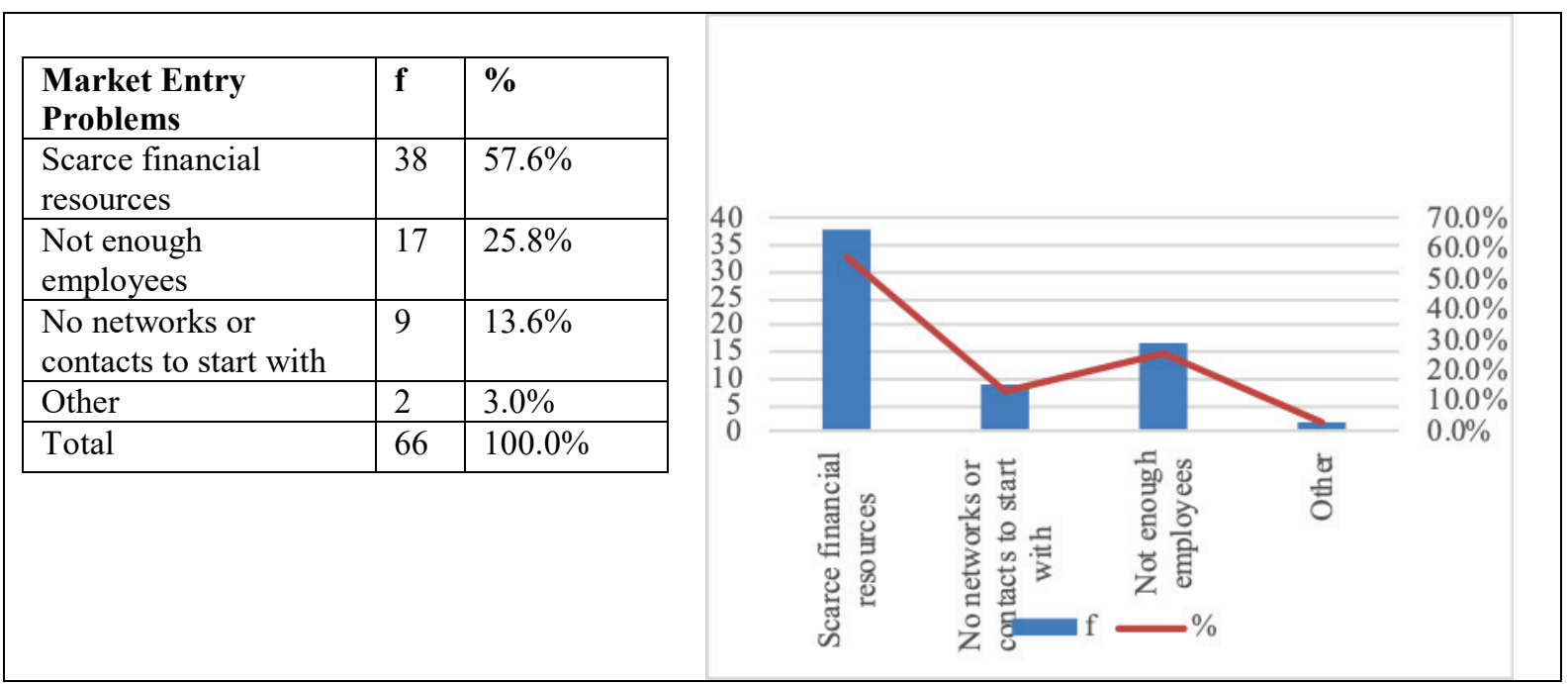

Figure 2 The Problems and Challenges Faced by Women from Ethnic Minorities When Entering the Market (EMWOSE, 2020)

However, the survey showed that the biggest challenge for women from ethnic minorities is language of the country they live. And it could influence other challenges as communication problems, problems of socialisation with locals, lack of contacts/networking.

\begin{tabular}{|c|c|c|c|c|}
\hline Motivating Factors & f & $\%$ & $\begin{array}{l}60-\longrightarrow \\
50\end{array}$ & $\begin{array}{l}50.0 \% \\
45.0 \% \\
40.0 \%\end{array}$ \\
\hline Social impact & 50 & $47.6 \%$ & 40 & \\
\hline Work life balance & 38 & $36.2 \%$ & 20 & \\
\hline Flexible working hours & 31 & $29.5 \%$ & 0 & \\
\hline Salary / payment & 23 & $21.9 \%$ & & \\
\hline Location of the business & 11 & $10.5 \%$ & & \\
\hline Other & 5 & $4.8 \%$ & & \\
\hline Total & $158^{*}$ & $150.5 \% *$ & $f-\%$ & \\
\hline
\end{tabular}

*: Participants can respond with multiple answers. Hence total frequency (158) is more than the number of participants (105). Thus, the total response is more than $100 \%$.

Figure 3 The Motivating Factors for You to Start or to Work in Social Business (EMWOSE, 2020)

Finding opportunities. The research has identified motivation as a factor to overcome the challenges and problems. The most frequent factor of motivation to work in social enterprise is social impact by $47.6 \%$. The following factor is 
work-life- balance by $36.2 \%$. The next one is flexible working hours by $29.5 \%$, which also can be related to work-life balance. Salary/payment, location of the business, and the others are the least motivational factors (Figure 3).

The participants were also asked whether they have been offered any supports/guidance by intuitions regarding funding their business. 27 (26.7\%) of the participants marked "yes", while, 47 participants (44.8\%) marked "no".

\begin{tabular}{|c|c|c|c|c|}
\hline & & & \multirow{8}{*}{$\begin{array}{r}40 \\
35 \\
30 \\
25 \\
20 \\
15 \\
10 \\
5 \\
0\end{array}$} & \multirow{8}{*}{$\begin{array}{l}40.0 \% \\
35.0 \% \\
30.0 \% \\
25.0 \% \\
20.0 \% \\
15.0 \% \\
10.0 \% \\
5.0 \% \\
0.0 \%\end{array}$} \\
\hline Institutions & f & $\%$ & & \\
\hline Local authorities & 36 & $34.3 \%$ & & \\
\hline Other & 26 & $24.8 \%$ & & \\
\hline Government & 15 & $14.3 \%$ & & \\
\hline Business sector & 14 & $13.3 \%$ & & \\
\hline European Union & 6 & $5.7 \%$ & & \\
\hline Total & $97 *$ & $92.4 \% *$ & & \\
\hline
\end{tabular}

Figure 4 Institutions Have Offered Support to Women from Ethnic Minorities in Founding Business (EMWOSE, 2020)

The respondents mentioned that almost the one-third (1/3) of them (36 participants) answered that local authorities helped them. They also got help from the government $(\mathrm{f}=15)$, the business sector $(\mathrm{f}=14)$, and European Union $(\mathrm{f}=6)$. Some participants $(\mathrm{f}=26)$ also received help from other institutions (Figure 4).

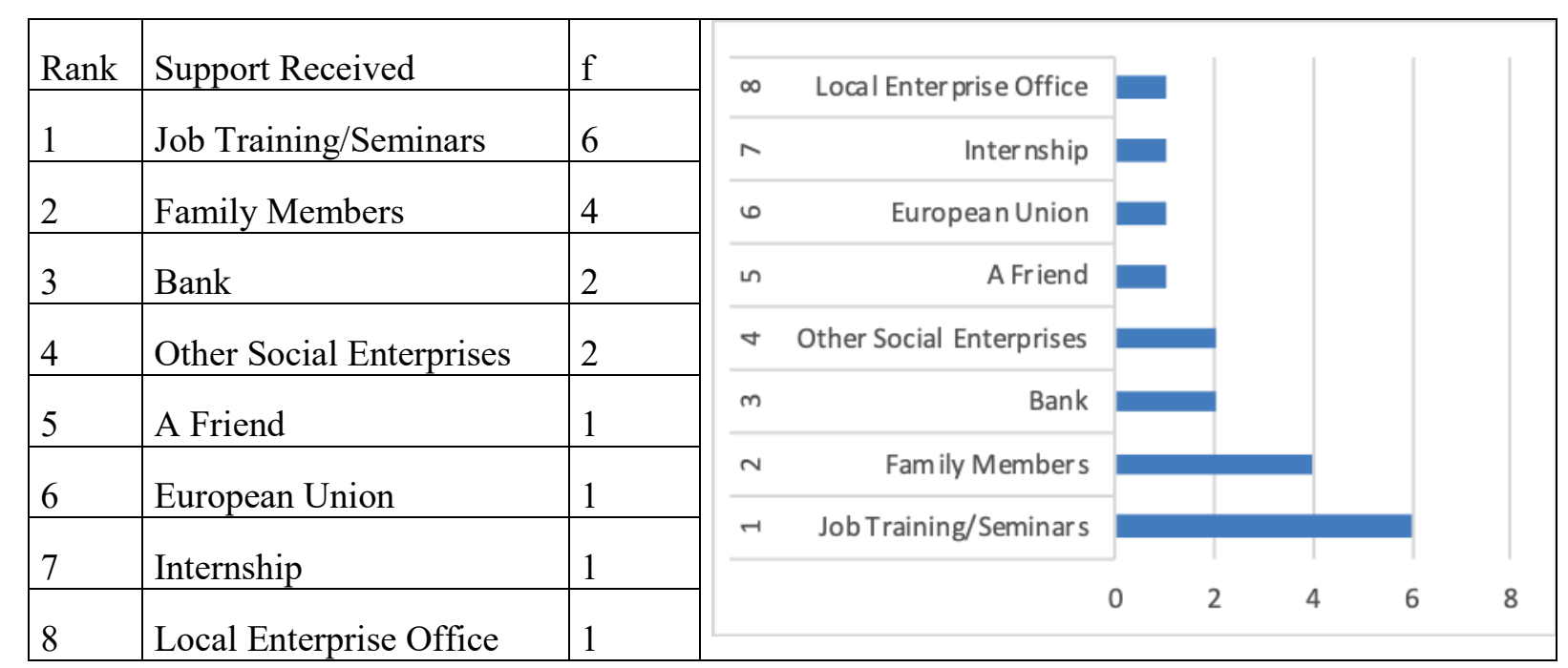

Figure 5 Support Has Got by Women from Ethnic Minorities (EMWOSE, 2020) 
Christauskas \& Žilione, 2021. Social Enterprise for Empowerment of Women From Ethnic Minority: Challenges And Possibilities

When looked at the type of the support institutions offered to the women form ethnic minorities: $42.9 \%(\mathrm{f}=45)$ financial support, and $39 \%(\mathrm{f}=41)$ mentoring and coaching; $39 \%(\mathrm{f}=41)$ training, $23.8 \%(\mathrm{f}=25)$ have received other type of support. The supports offered are several, but the most offered one is job training/seminars. The next one is by family members. It is followed by banks and other social enterprises.

In the survey, the experts were also asked the advice they would offer to other women who want to return to the workplace/ to start their own business/ to get a job.

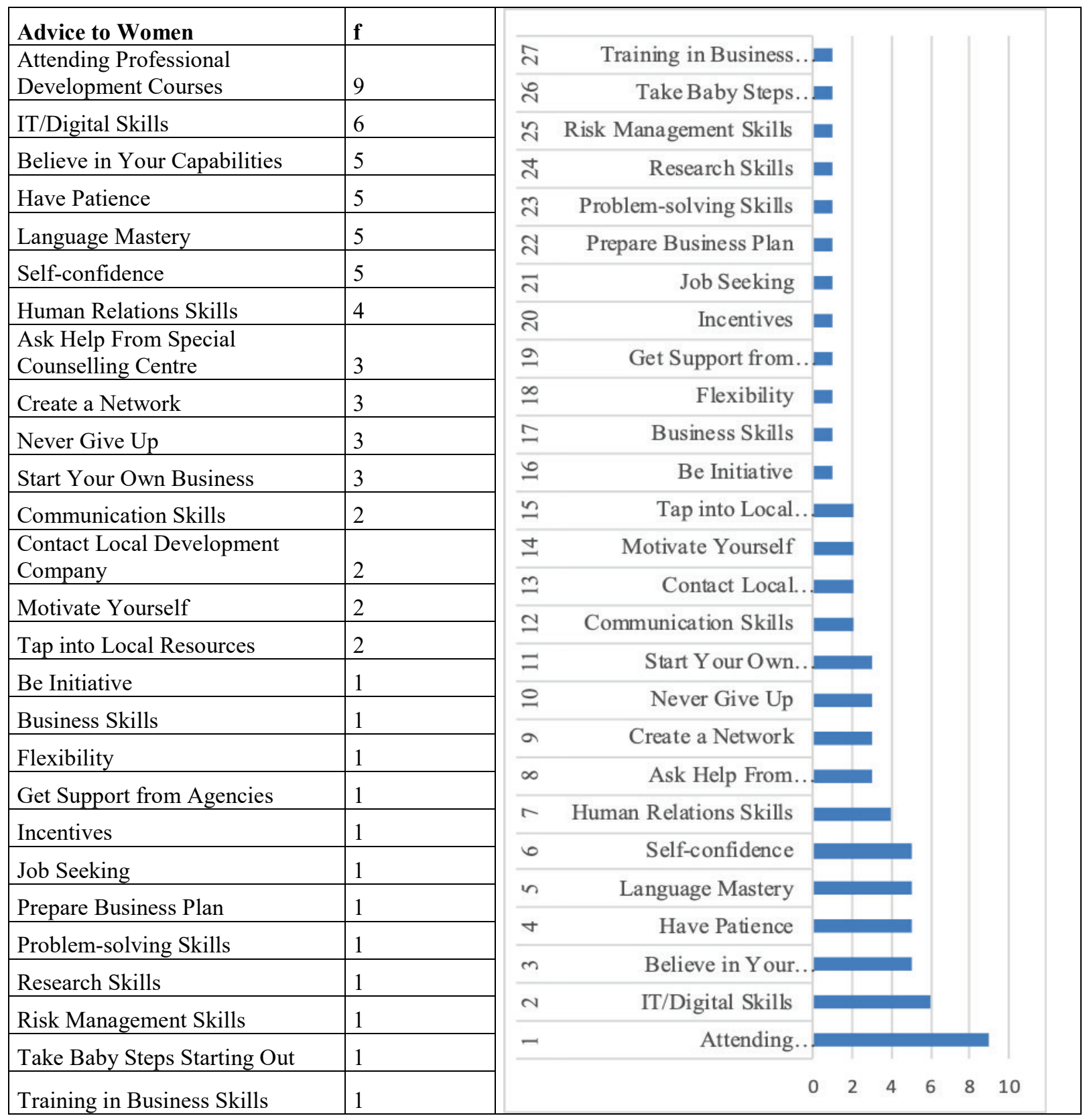

Figure 6 Experts' Advises to Women from Ethnic Minorities Who Want to Return to the Workplace/ to Start Their Own Business/ to Get a Job (EMWOSE, 2020) 
The most popular advice given was attending professional development courses. It was also advised to have developed IT/digital skills. Believing in one's capabilities, having patience, mastering language, and self-confidence follows them. The next one is human relations skills which also does not share the same number of advisers with other suggestions (Figure 6).

The research showed that women from ethnic minorities are not alone with challenges of business, they can get support either from local authorities or government. The most frequent answer to overcome issues was provided as educational offer to develop necessary competencies.

\section{Conclusions}

Work is considered the best way to empower women economically. Analysis of scientific literature highlighted that social entrepreneurship has been key in promoting women empowerment.

Survey results of quantitative and qualitative data revealed challenges that women from ethnic minorities have faced and what opportunities they have while working in social enterprise.

Referring to survey results, more than $50 \%$ of women from ethnic minorities faced communication problems/language barriers (avg. 3.45) while developing social business. Moreover, it may be assumed that it also influences other challenges as communication problems, problems of socialisation with locals, lack of contacts/networking.

The results of the study revealed that almost $60 \%$ of women form ethnic minorities complain about the lack of financial resources while entering the market of social business. After summarising the results of the survey results, lack of human resources (more than 25\%) could be also considered as a reason of the lacking financial resources.

After analysis of the obtained results, it was found that women from ethnic minorities are able to overcome these challenges with the help of their motivation (social impact: almost 50\%, work life balance: almost $40 \%$, flexible working hours: almost $30 \%$, which also can be related to work-life balance) and support of others: mostly by local authorities (more than 30\%). The survey has especially highlighted the need to develop lacking competencies by women from ethnic minorities in order to run social business.

\section{References}

Biggeri, M., Testi, E., Bellucci, M., During, R., H. \& Persson, Th. R. (2018). Social Entrepreneurship and Social Innovation: Ecosystems for Inclusion in Europe. Routledge. 
Christauskas \& Žilione, 2021. Social Enterprise for Empowerment of Women From Ethnic

Minority: Challenges And Possibilities

Briar-Lawson, K., Miesing, P., \& Ramos, B. M. (2020). Social Entrepreneurship and Enterprises in Economic and Social Development. Oxford University Press.

Doss, C., Malapit, H. J., \& Comstock, A. (2020). Methods for measuring women's empowerment. PIM Synthesis Brief.

EMWOSE. (2020). Empowering Women from Ethnic Minorities through Social Enterprise: State of the Art Report. Retrieved from https://emwose.eu/wpcontent/uploads/2020/06/EMwoSE-state-of-the-Art-Report.pdf

European Commission. (2021). Women's situation in the labour market. Retrieved from https://ec.europa.eu/info/policies/justice-and-fundamental-rights/gender-

equality/women-labour-market-work-life-balance/womens-situation-labour-market_en

European Institute for Gender Equality. (2021). Gender Equality Index. Retrieved from https://eige.europa.eu/gender-equality-index/2020/country

European Parliament. (2020). REPORT on the EU Strategy for Gender Equality (2019/2169(INI)). Retrieved from https://www.europarl.europa.eu/doceo/document/A9-2020-0234 EN.html

Hemalatha, M. (2020). Women Empowerment And Tourism Industry. International Journal Of Multidisciplinary Educational Research, 9, 1(2), 219-224.

Mandal, K. C. (2013). Concept and Types of Women Empowerment. International Forum of Teaching and Studies, 9, 2, 17-30.

Petesch, P., Smulovitz, C., \& Walton, M. (2005). Evaluating Empowerment: A Framework with Cases from Latin America. Measuring Empowerment: Cross-Disciplinary Perspectives. Ed. Narayan D. ISBN 0-8213-6057-4

Siba, E. (2019). Empowering women entrepreneurs in developing countries: Why current programs fall short. Africa Growth Initiative at Brookings. Policy Brief. Retrieved from https://think-asia.org/bitstream/handle/11540/9976/Empowering-women-entreprenuersin-developing-countries-190215.pdf? sequence $=1$

United Nations. (2015). Transforming our world: the 2030 Agenda for Sustainable Development. Resolution adopted by the General Assembly on 25 September 2015. Retrieved from https://www.un.org/ga/search/view_doc.asp?symbol=A/RES/70/1\&Lang=E

United Nations. (2019). International Migration 2019: Report (ST/ESA/SER.A/438). Retrieved from https://www.un.org/en/development/desa/population/migration/ publications/migrationreport/docs/InternationalMigration2019_Report.pdf 